\title{
PENINGKATAN KETERAMPILAN PROSES DASAR SISWA MELALUI MODEL DISCOVERY LEARNING KELAS VII 2 SMPN 8 KOTA BENGKULU
}

\author{
Fitri Yanti ${ }^{1 *}$, Irdam Idrus ${ }^{1}$, Sri Irawati ${ }^{1}$ \\ ${ }^{1}$ Program Studi Pendidikan Biologi, Fakultas Keguruan dan Ilmu Pendidikan, Universitas Bengkulu \\ Email: fitriqila17@gmail.com
}

\begin{abstract}
Abstrak
Penelitian ini bertujuan untuk mendeskripsikan keterampilan proses IPA dan siswa menggunakan model discovery learning dan meningkatkan keterampilan proses dasar siswa kelas VII2 SMPN 8 Kota Bengkulu. Jenis penelitian ini adalah penelitian tindakan kelas yang dilakukan dalam dua siklus. Setiap siklus penelitian ini terdiri atas empat tahap yaitu perencanaan, pelaksanaan, pengamatan, refleksi. Pembelajaran IPA biologi yang menggunakan model discovery learning dengan dengan pemberian rangsangan, identifikasi masalah, pengumpulan data, pengelolaan data, pembuktian, dan menarik kesimpulan. Hasil penelitian yang telah dilakukan menunjukkan bahwa pembelajaran dikategorikan baik dari siklus I dengan rerata skor 20,5 (baik) dan di siklus II dengan rerata skor 23,5 (baik). Kegiatan guru yang belum optimal pada siklus I telah dilakukan perbaikan pada siklus II akan tetapi masih ada kegiatan yang belum optimal di siklus II yaitu membimbing siswa untuk mendiskusikan hasil pengamatan (pengelolaan data). Keterampilan proses dasar siswa yang di teliti berdasarkan keterampilan kelompok siswa dalam melakukan penyelidikan, tahap yang dilakukan adalah pengamatan, mengklasifikasikan, menginferensi dan mengkomunikasikan. Keterampilan proses dasar siswa pada pembelajaran yang teleh dilakukan siklus I dikategorikan baik dengan rerata skor 15,5 (baik) dan meningkat pada siklus II dengan rerata skor 17,5 (baik). Kesimpulannya bahwa dengan menggunakan model discovery learning maka dapat meningkatkan keterampilan proses dasar siswa.
\end{abstract}

Kata Kunci: Discovery Learning, Keterampilan Proses Dasar

\begin{abstract}
This study aims to describe the science process skills and students use discovery learning models and improve the basic process skills of class VII2 students of SMP 8 Kota Bengkulu. This type of research is classroom action research conducted in two cycles. Each cycle of this research consists of four stages, namely planning, implementing, observing, reflecting. Biology science learning that uses discovery learning models in this study is the teacher's activities at the stage of stimulation, problem identification, data collection, data management, verification, and drawing conclusions measured using observation sheets. The results of the research that has been done show that learning is categorized as good from cycle I with a mean score of 20.5 (good) and in cycle II with a mean score of 23.5 (good). Teacher activities that have not been optimal in cycle I have been improved in cycle II, but there are still activities that are not optimal in cycle II, namely guiding students to discuss the results of observations (data management). The basic process skills of students who are researched based on the skills of the student group in carrying out the investigation, the steps taken are observing, classifying, referring and communicating. The skills of the students' basic processes in the rigorous learning carried out in cycle I were categorized as good with a mean score of 15.5 (good) and increased in cycle II with a mean score of 17.5 (good). The conclusion is that by using discovery learning models it can improve students' basic process skills.
\end{abstract}

Keywords: Discovery Learning, Basic Student, Process Skills

DOI: https://doi.org/10.33369/diklabio.3.2.240-249 


\section{PENDAHULUAN}

Pendidikan merupakan usaha untuk meningkatkan potensi dirinya agar memiliki kecerdasan dan keterampilan. Trianto (2011) mengungkapan bahwa dengan pendidikan, manusia dapat memiliki kepribadian, kecerdasan dan akhlak mulia. Usaha yang nyata diperlukan untuk

Berdasarkan observasi awal yang dilakukan oleh peneliti terhadap pembelajaran IPA di kelas $\mathrm{VII}_{2}$ SMPN 8 Kota Bengkulu tahun ajaran 2017/2018, masalah yang ditemukan pada proses pembelajaran adalah kurang tepatnya strategi pembelajaran yang dilakukan guru sehingga pada proses pembelajaran siswa terpaku pada buku. Percobaan/pengamatan yang dilakukan guru. Guru berpendapat bahwa apabila melakukan percobaan/pengamatan menimbulkan siswa banyak bermain tanpa memperhatikan apa yang dibicarakan guru dan materi yang sedang dipelajari, sehinggamenyebabkan siswa sulit untuk mengembangkan keterampilan proses yang dimiliki siswa. Dari hasil pengamatan selama magang tiga siswa banyak yang mengalami kesulitan dalam mengembangkan keterampilannya. Menurut Zubaidah dalam (Ibrohim dkk., 2014) Keterampilan melakukan proses sains dikelompokkan menjadi dua macam, yakni keterampilan proses dasar dan keterampilan proses terintegrasi. Keterampilan proses dasar meliputi kegiatan observasi, klasifikasi, pengukuran, komunikasi, inferensi, dan prediksi. Keterampilan proses terintegrasi meliputi merumuskan hipotesis, mengontrol variabel, merumuskan masalah, dan menginterpretasi data. Keterampilan proses IPA adalah bagian dari keterampilan ilmiah, selain keterampilan penalaran dan keterampilan berpikir ktitis. Oleh sebab itu peneliti melakukan penelitian keterampilan dasar untuk melihat keterampilan proses yang dimiliki siswa karena guru hanya mendemostrasikan materi yang seharusnya dilakukan pengamatan, sehingga menyebabkan siswa kurang memiliki rasa ingin tahu dan kurang termotivasi untuk memahami konsep dalam pembelajaran. Hal ini dapat dilihat dari rendahnya nilai siswa karena nilai kreteria ketuntasan minimal (KKM) siswa SMPN 8 Kota Bengkulu sebesar 75 akan tetapi pada saat ulangan harian dilakukan hanya 4 orang yang mendapatkan nilai di atas KKM sehingga membuat siswa yang belum memenuhi KKM harus mengikuti ulangan harian lagi hingga memenuhi KKM.

Berdasarkan permasalahan tersebut peneliti berkeinginanmelakukan penelitian melihat gambaran keterampilan proses dasar yang dimiliki siswa. Oleh karena itu, peneliti berkerjasama dengan guru mata pelajaran IPA Biologi SMPN 8 Kota Bengkulu dan untuk melakukan perbaikan pembelajaran di kelas $\mathrm{VII}_{2}$ SMPN 8 Kota Bengkulu yaitu dengan penerapan model pembelajaran penemuan (discovery learning) pada materi pencemaran lingkungan untuk meningkatkan keterampilan proses dasar siswa. Peneliti menggunakan model pembelajaran discovery learning karena model ini sangat cocok untuk meningkatkan keterampilan proses dasar siswa, yang bertujuan agar siswa dapat lebih aktif dalam proses pembelajaran dan model pembelajaran discovery learning juga menuntut guru untuk membimbing siswa dalam memecahkan masalahnya sendiri, sehingga mampu melatih siswa mengembangkan keterampilan.

Rumusan masalah dalam penelitian ini adalah: (1) Bagaimana cara penerapan model pembelajaran discovery learning materi pencemaran lingkungan pada kegiatan mengajar guru dan proses 
pembelajaran IPA siswa kelas $\mathrm{VII}_{2}$ SMPN 8 Kota Bengkulu? (2) Apakah penerapan model discovery Learning pada materi pencemaran lingkungan dapat meningkatkan keterampilan proses dasar IPA siswa di kelas $\mathrm{VII}_{2}$ SMPN 8 Kota Bengkulu?

Tujuan penelitian ini adalah: Tujuan pada penelitian ini adalah: (1) Mendeskripsikan penerapan model pembelajaran discovery learning materi pencemaran lingkungan pada kegiatan mengajar guru dan proses pembelajaran IPA siswa kelas $\mathrm{VII}_{2}$ SMPN 8 Kota Bengkulu. (2) Untuk meningkatkan keterampilan proses dasar IPA siswa menggunakan model discovery learning pada materi pencemaran lingkungan kelas $\mathrm{VII}_{2}$ SMPN 8 Kota Bengkulu.

\section{METODE}

Jenis penelitian ini adalah Penelitian Tindakan Kelas (PTK). Metode Penelitian yang digunakan adalah metode desktiptif untuk mencapai suatu tujuan penelitian. Subjek dalam penelitian ini adalah guru IPA dan siswa kelas $\mathrm{VII}_{2}$ SMPN 8 Kota Bengkulu Tahun Ajaran 2017/2018. Kumlah siswa yaitu 32 orang yang terdiri dari 17 orang lakilaki dan 15 orang perempuan.

Variabel penelitian ini terdiri dari variabel bebas yaitu pembelajaran IPA menggunakan model discovery learning. Sedangkan variabel terikat terdiri dari aktivitas guru dan siwaa serta keterampilan proses dasar siswa.

Keterampilan proses yang dikembangkan terdiri dari empat indikator keterampilan proses dasar yaitu mengoservasi, mengklasifikasi, menyimpulkan, dan mengkomunikasikaan. Instrumen yang digunakan untuk mengumpulkan data keterampilan proses yaitu lembar observasi. Lembar observasi digunakan untuk melihat keterampilan keterampilan proses dasar siswa yang diamati oleh 2 orang observer.

Teknik yang digunakan untuk mengumpulkan data pembelajaran menggunakan model discovery learning adalah observasi dan intrumen yang digunakan yaitu lembar observasi. Teknik yang digunakan untuk keterampilan proses dasar siswa menggunakan observasi Penelitian ini dilakukan dalam dua siklus.

Teknik analisis data hasil kegiatan guru dalam proses pembelajaran IPA biologi model discovery learning dilihat menggunakan lembar observasi guru dianalisis secara deskriptif dengan menghitung rerata dan kategori skor dengan ketetapan yaitu baik, cukup, kurang.

$$
\text { Rerata skor }=\frac{\Sigma X}{N}
$$

(Sudijono, 2014)

Menghitung kisaran rerata dengan rumus:

Kategori skor $=\frac{\text { skor tertinggi-skor terendah }}{\text { Jumlah kategori penilaian }}$

(Arikunto, 2013)

Data keterampilan proses dasar siswa dianalisis dengan menggunakan rerata, rentang kategori skor dengan ketetapan yaitu baik, cukup, kurang.

$$
\text { Rerata skor }=\frac{\Sigma X}{N}
$$

(Sudijono, 2014)

Untuk menentukan kategori rerata pada aspek-aspek keterampilan proses siswa dengan menggunakan rumus:

Kategori skor $=\frac{\text { skor tertinggi-skor terendah }}{\text { Jumlah kategori penilaian }}$

(Arikunto, 2013)

\section{HASIL DAN PEMBAHASAN}

Penelitian tindakan kelas yang menggunakan model pembelajaran discovery learning dilakukan dalam 2 siklus pembelajaran di kelas $\mathrm{VII}_{2}$ SMPN 8 Kota 
Bengkulu pada materi pencemaran lingkungan dalam upaya untuk meningkataan keterampilan proses dasar siswa yang telah dilaksanakan dalam dua siklus, diperoleh hasil sebagai berikut ini.

\section{Pembelajaran IPA Biologi dengan Model Discovery Learning}

Pembelajaran IPA biologi dengan menggunakan model discovery learning pada materi Pencemaran Lingkungan terhadap kedua siklus telah dinilai baik oleh kedua pengamat. Rerata skor dan kategori skor hasil observasi guru pada pembelajaran discovery learning dilihat pada Tabel 1.

Tabel 1. Data hasil aktivitas Guru siklus I dan iklus II

\begin{tabular}{|c|c|c|c|}
\hline \multirow{2}{*}{ No } & \multirow{2}{*}{ Pengamat } & \multirow{2}{*}{$\begin{array}{l}\text { Siklus I } \\
\text { Skor }\end{array}$} & \multirow{2}{*}{$\begin{array}{l}\text { Siklus II } \\
\text { Skor }\end{array}$} \\
\hline & & & \\
\hline 1 & 1 & 19 & 23 \\
\hline 2 & II & 20 & 24 \\
\hline \multicolumn{2}{|c|}{ Total Skor } & 39 & 47 \\
\hline \multicolumn{2}{|c|}{ Rerata Skor } & 19,5 & 23,5 \\
\hline \multicolumn{2}{|c|}{ Kriteria } & Baik & Baik \\
\hline
\end{tabular}

Proses penerapan model discovery learning yang dilakukan pada siklus I dan II sesuai dengan tahapan model discovery learning menurut Widiasworo (2017) yaitu: pemberian rangsangan, pernyataan/identifikasi masalah, pengumpulan data, pengolahan data, pembuktian, dan meranik kesimpulan/geleralisaasi.

Proses pembelajaran dengan menerapkan model discovery learning yang diamati melalui lembar observasi kegiatan pembelajaran guru secara umum dikategorikan baik pada siklus I dan siklus II. Penerapan model discovery learning pada kegiatan pembelajaran guru mengalami peningkatan dari siklus I ke siklus II yang ditunjukkan dengan meningkatnya rerata perolehan skor secara keseluruhan dan meningkatnya pada setiap aspek yang diamati sesuai dengan tahapan model discovery learning pada kedua siklus tersebut.

Berdasarkan hasil penelitian menggunakan model discovery learning melalui pembelajaran IPA biologi pada materi Pencemaran Lingkungan dalam dua siklus dengan pembelajaran IPA biologi dengan tahapan model discovery learning sebagai berikut:

\section{a. Stimulasi/Pemberian Rangsangan}

Pada tahap pemberian rangsangan di siklus I sudah berjalan dengan baik. Pada tahap ini, guru memberikan motivasi belajar kepada siswa dengan menunjukkan gambar beberapa contoh dan sumber pencemaran lingkungan yang sesuai dengan tofik penbelajaran tentang Definisi Pencemaran Lingkungan yaitu melihat contoh dan sumber-sumber dari pencemaran lingkungan. Kegiatan guru di tahap siklus II dilakukan pada dasar refleksi yang telah dilaksanakan pada siklus I sehingga proses pembelajaran di siklus II tetep berjalan dengan baik. Di tahap siklus II, guru melakukan pembelajaran dengan sub materi Pencemaran Air yang menampilkan gambar tentang pencemaran lingkungan. Pemberian rangsangan yang diberikan guru diambil berdasarkan kejadian yang sering siswa lihat dan lakukan di dalam kehidupan sehari-hari, agar pemberian rangsangan tersebut dapat memunculkan masalah dengan memperhatikan gambar yang diberikan oleh guru. Menurut Widiasworo (2017), pemberian rangsangan atau stimulus pada awalnya pembelajaran merupakan hal yang sangat penting dan harus dilakukan oleh guru. Pada tahap ini, peserta didik terlebih dahulu dihadapkan pada permasalahan yang belum dimengerti. Selanjutnya, guru memberikan generalisasi agar peserta didik termotivasi untuk mengadakan penyelidikan tentang masalah tersebut. 


\section{b. Pernyataan/Identifikasi Masalah}

Pada tahap identifikasi masalah sudah berjalan dengan baik di siklus I. Pada tahap ini guru sudah baik mengarahkan kelompok siswa untuk proses identifikasi masalah. Pada materi definisi pencemaran lingkungan guru sudah dapat membimbing siswa mengemukakan pendapatnya dengan memberikan pertanyaan bantuan yang diajukan oleh guru sesuai dengan materi dan permasalahan yang sedang di bahas yaitu "pencemaran lingkungan seperti apa saja yang kalian ketahui?". Kegiatan guru pada tahap siklus II berdasarkan refleksi yang dilakukan di kegiatan siklus I maka tetap dinilai baik oleh kedua pengamat. Pada siklus II guru sudah baik mengarahkan kelompok siswa untuk proses identifikasi masalahsesuai dengan sub materi pencemaran air serta memberikan pertanyaan yaitu: "pernahkah kalian melihat air yang sudah tercemar dalam lingkungan sehari-hari?". Pertanyaan yang diberikan pada siklus I dan siklus II berfungsi agar mendorong siswa untuk meningkatkan kemampuan berfikirnya. Menurut John I Bolla (1985) dalam Rusman (2014) menyatakan bahwa dalam proses pembelajaran perlu dilakukan kegiatan yang dapat menuntut respon siswa baik berupa kalimat tanya maupun kalimat perintah agar siswa memperoleh pengetahuan dan meningkatkan kemampuan berfikir serta dapat meningkatkan partisipasi siswa dalam kegiatan pembelajaran sehingga proses pembelajaran berpusat aktif pada siswa. Sedangkan menurut Buana (2017) memberikan kesempatan siswa untuk mengidentifikasi dan menganalisis permasasalahan yang mereka hadapi, merupakan teknik yang berguna dalam membangun siswa agar mereka terbiasa untuk menemukan suatu masalah.

\section{c. Pengumpulan Data}

Pada tahap pengumpulan data terdapat dua aspek kegiatan pembelajaran guru yaitu: mengistruksikan siswa untuk melakukan pengamatan dan membimbing siswa dalam melakukan pengamatan. Menurut Widiasworo (2017) Tahapan pengumpulan data adalah aktivitas mengambil informasi dalam rangka menguji kebenaran hipotesis. Sedangkan menurut Lestari (2016) bahwa untuk menjawab pertanyaan atau membuktikan hipotesis, anak didik diberi kesempatan untuk mengumpulkan data dan informasi yang dibutuhkan untuk mengumpulkan data dan informasi yang dibutuhkan, seperti wawancara dengan narasumber, melakukan uji coba sendiri, dan lain sebagainya. Pada tahap pengumpulan data ini, peserta didik diberi kesempatan untuk mengumpulkan berbagai informasi yang relevan, membaca literatur, mengamati objek, wawancara dengan narasumber, melakukan uji coba sendiri, dan sebagainya.

Pada tahap menginstruksikan siswa untuk melakukan pengamatan di nilai belum optimal oleh pengamat sehingga pengamat hanya memberi nilai cukup, hal ini terjadi karena guru tidak memperhatikan seluruh kelompok dimana guru hanya terfokus pada kelompok yang depan saja sehingga kelompok paling belakang tidak terlalu memperhatikan instruksi yang diberikan oleh guru. Kegiatan guru di siklus II dilakukan berdasarkan refleksi di siklus I. Pada siklus II tahap menginstruksikan siswa untuk melakukan pengamatan sudah dilakukan secara optimal oleh guru sehingga kegiatan guru sudah berjalan dengan baik.

Kegiatan guru selanjutnya yaitu membimbing siswa dalam melakukan pengamatan, pada tahap ini belum juga berjalan dengan baik karena guru masih belum memperhatian seluruh kelompok untuk melakukan pengamatan sehingga 
menyebabkan kedua pengamat memberikan nilai cukup (C). Pengamatan yang dilakukan yaitu melihat perbedaan air yang tercemar dengan air yang tidak tercemar. Kegiatan pembelajaran di siklus II dilakukan berdasarkan hasil refleksi di siklus I sehingga tahap pengamatan berlangsung sudah berjalan dengan baik. Di tahap ini pengamatan dilakukan dengan melihat keadaan ikan jika hidup di air yang tercemar dan air yang tidak tercemar. Guru sudah mampu membimbing siswa untuk melakukan pengamatan dengan baik sesuai yang diharapkan.

\section{d. Pengolahan Data}

Pada tahap pengumpulan data terdapat dua aspek kegiatan pembelajaran guru yaitu: membimbing siswa untuk mendiskusikan hasil pengamatan dan membimbing siswa untuk menjawab pertanyaan berdasarkan pengamatan. Pada aspek membimbing siswa untuk mendiskusikan hasil pengamatan di siklus I belum dilakukan secara maksimal oleh guru hal ini terjadi karena guru tidak membimbing seluruh kelompok untuk mendiskusikan hasil pengamatan sehingga siswa sebagian kelompok melakukan diskusi tidak mendapatkan bimbingan guru secara optimal. Pada siklus II yang dilakukan berdasarkan hasil refleksi siklus I, pengamat satu menilai guru belum juga membimbing siswa secara optimal karena masih ada kelompok yang tidak dibimbing secara optimal.

Pada tahap selanjutnya yaitu aspek membimbing siswa untuk menjawab pertanyaan berdasarkan pengamatan. Pada aspek di siklus I belum dilakukan secara optimal oleh guru karena guru belum juga membimbing seluruh kelompok siswa di dalam kelas. Hal tersebut terjadi karena guru belum juga terlalu memperhatikan kelompok yang berada di belakang.
Pertanyaan yang diberikan yaitu berupa soal-soal yang terdapat di dalam LKS yang sesusai dengan percobaan yang dilakukan. Pada siklus II di tahap ini pengamat menilai guru sudah melakukan pengamatan secara optimal dan baik. Dimana guru sudah membimbing siswa untuk menyawab pertanyaan yang terdapat di dalam LKS yang soalnya sesuai dengan pengamatan yang dilakukan. Menurut Lestari (2016) Semua informasi hasil bacaan wawancara dengan observasi diklasifikasikan dan ditabulasi, bahkan bila perlu dihitung dengan cara tertentu, serta ditasfsirkan pada tingkat kepercayaan tertentu.

\section{e. Pembuktian}

Pada tahap pembuktian dilakukan kerena untuk membuktikan yang telah dilakukan pada tahap pengelolaan data. Ditahap ini guru membimbing siswa untuk melakukan pembuktian dengan cara mengistruksikan siswa untuk mencocokkan hasil dengan literatur berupa buku atau internet. Pada siklus I, tahap ini sudah dilakukan secara optimal dan baik oleh guru. Sikus II dilakukan berdasarkan hasil refleksi siklus I. Pada siklus II guru juga sudah membimbing siswa melakukan pembuktian yang sesuai dengan literatur atau internet. Proses pembuktian dapat berlangsung dengan baik karena siswa memiliki buku pelajaran IPA yang dipinjamkan oleh pihak sekolah, oleh karena itu siswa dapat melihat contoh-contoh pencemaran yang terjadi di kehidupan sehari-hari mereka. Merurut Widiasworo (2017), pembuktian bertujuan untuk memberikan pengalaman pembelajaran yang bermakna, karena pesarta didik diberi kesempatan seluasluasnya untuk menemukan konsep tiori, aturan, pemahaman, melalui contoh yang dijumpai dalam kehidupan.

\section{f. Generalisasi/Menarik Kesimpulan}


Pada kegiatan guru ditahap menarik kesimpulan dengan aspek membimbing siswa untuk menyimpulkan hasil pengamatan di siklus I. Pada tahap ini guru sudah melakukan dengan optimal dan baik. Ditahap ini guru sudah membimbing siswa untuk menyimpulkan hasil pengamatan yang sudah dilakukan berdasarkan pertanyaan yang terdapat dalan soal LKS. Guru melakukan refleksi pada siklus II berdasarkan pembelajaran yang berlangsung di siklus I sehingga di tahap ini guru masih membimbing siswa untuk menarik kesimpulan secara optimal dan baik berdasarkaan soal yang terdapat di dalam LKS siklus II. Menurut Widiasworo (2017), dalam pembelajaran menarik kesimpulan merupan suatu keharusan, agar peserta didik dapat menemukan jawaban setelah melalui proses berfikir dalam mencari data kesimpulan akan mengantar peserta didik pada sebuah bentuk pengetahuan yang akurat.

Berdasarkan penelitian yang dilakukan pada pembelajaran menggunakan model discovery learning di siklus I dan di siklus II memiliki kesulitan untuk mengatur seluruh siswa dalam proses pembelajaran berlangsung dan menelolah waktu agar guru dapat membimbing seluruh siswa untuk melakukan proses bembelajaran.

\section{Keterampilan Proses Dasar Siswa}

Pengamatan terhadap keterampilan proses dasar siswa pada proses pembelajaran IPA biologi dengan menggunakan model discovery learning pada materi pencemaran lingkungan terhadap kedua siklus telah dinilai baik oleh kedua pengamat. Rerata skor dan kategori skor hasil observasi keterampilan proses dasar siswa pada pembelajaran discovery learning dilihat pada Tabel 2.
Tabel 2. Data hasil Keterampilan Proses dasar Siswa siklus I dan iklus II

\begin{tabular}{llll}
\hline \multirow{2}{*}{ No } & \multirow{2}{*}{ Pengamat } & Siklus I & Siklus II \\
\cline { 2 - 4 } & Skor & Skor \\
\hline 1 & I & 15 & 17 \\
2 & 16 & 18 \\
Total Skor & 31 & 35 \\
Rerata Skor & 15,5 & 17,5 \\
Kriteria & Baik & Baik \\
\hline
\end{tabular}

Berdasarkan pembelajaran IPA biologi yang dilakukan selama dua siklus menggunakan model discovery learning, bahwa model discovery learning dapat meningkatkan keterampilan proses dasar siswa pada materi Pencemaran Lingkungan. Menurut Dimyati (2015) keterampilan proses dasar yakni mengobservasi, mengklasifikasi, memprediksi, mengukur, menyimpulkan, dan mengkomunikasikan. Pada penelitian ini tahap yang dilihat berupa mengobservasi, mengklasifikasi, menyimpulkan, dan mengkomunikasikan. Siklus I materi yang di sampaikan berupa Definisi Pencemaran Lingkungan dan pada siklus II materi yang disampaikan berupa Pencemaran Air.

Berdasarkan data analisis hasil penelitian pada keterampilan proses dasar siswa yang melalui tahapan pada ketempilan proses dasar siswa sebagai berikut:

\section{a. Mengobservasi/pengamatan}

Pada tahap pengamatan di siklus I sudah berjalan dengan baik. Pada tahap ini siswa melakukan pengamatan dan mencatat hasil pengamatan yang telah siswa lakukan dengan bimbingan guru. Pengamatan yang diamati adalah perbedaan air yang sudah tercemar dengan air yang tidak tercemar. Hasil yang siswa dapatkan pada pengamatan tersebut akan dicatat pada tabel pengamatan yang terdapat di dalam LKS. Berdasarkan refleksi siklus I maka dilakukan siklus II dengan kesiapan pengamatan terhadap kehidupan ikan apabila hidup di air 
yang tidak tercemar dan air yang belum tercemar. Hasil pengamatan yang siswa lakukan ditulis pada tebel hasil pengamatan dalam LKS. Menurut Dimyati (2015) kemampuan mengamati merupakan keterampilan yang paling dasar dalam proses dan memperoleh ilmu pengetahuan serta merupakan hal terpenting untuk mengembangkan keterampilanketerampilan proses lainnya. Mengamati merupakan tanggapan kita terhadap berbagai objek dan peristiwa alam dengan menggunakan pancaindra.

\section{b. Mengklasifikasi}

Pada tahap mengklasifikasikan di siklus I belum berjalan dengan optimal dan baik sehingga pengamat hanya memberi nilai cukup. Karena menurut pengamat siswa belum dapat mengelompokkan hasil pengamatannya, hal ini terjadi karena guru tidak mengamati seluruh kelompok siswa pada saat mengklasifikasikan hasil pengamatan yang sudah dilakukan. Pada siklus II tahap mengklasifikasikan salah satu pengamat mengatakan bahwa siswa belum juga melakukan pengklasifikasian secara optimal dan baik karena menurut pengamat guru masih kurang membimbing siswa dalam pengklasifikasian hasil pengamatan. Menurut Dimyati (2015) mengklasifikasikan merupakan keterampilan proses untuk memilah berbagai objek peristiwa berdassarkan sifat-sifat khususnya, sehingga didapatkan golongan/kelompok sejenis peristiwa yang dimaksud.

\section{c. Menginferensi}

Pada tahap menginferensi terdiri dari tiga aspek yang diamati yakni: menjelaskan data hasil pengamatan dengan menjawab soal pertanyaan, menghubungkan data hasil pengamatan pada kehidupan sehari-hari dengan menjawab pertanyaan, dan menyimpulkan data hasil pengamatan.
Pada aspek menjelaskan data hasil pengamatan dengan menjawab soal pertanyaan, di siklus I sudah dilakukan dengan optimal dan baik oleh siswa hal ini dapat dilakukan dengan baik karena siswa sudah mampu menjelaskan data hasil pengamatan, karena siswa dapat menjelaskannya dengan menjawab pertanyaan-pertanyaan yang sudah terdapat dalam LKS sehingga memudahkan siswa dalam menjelaskannya dengan baik. Berdasarkan hasil refleksi di siklus I, maka dilakukan siklus II yang sudah berjalan dengan baik dan optimal oleh siswa karena siswa sudah mengerti cara menjelaskan data hasil pengamatan seperti pada siklus I yang sudah dibimbing guru agar lebih memudahkan siswa dalam menjelaskan data hasil pengamatannya.

Aspek selanjutnya yang dilakukan pada tahap menginferensiasi adalah aspek menghubungkan data hasil pengamatan pada kehidupan sehari-hari dengan menjawab pertanyaan. Pada siklus I siswa belum menghubungkannya dengan optimal dan baik karena siswa belum mampu menghubungkan data hasil pengamatan pada kehidupan sehari-hari, hal ini terjadi karena siswa masih kebingungan untuk menghubungkan pengamatan yang mereka lakukan dengan kehidupan sehari-hari yang siswa jalani dan guru juga tidak optimal dalam membimbing siswa untuk menghubungkannya dengan kehidupan sehari-hari. Di siklus II yang sudah dilakukan refleksi berdasarkan siklus I proses menghubungkan data hasil pengamatan dengan kehidupan sehari-hari sudah berjalan dengan optimal dan baik, karena guru sudah dapat membimbing siswa untuk menghubungkan data hasil pengamatan pada kehidupan sehari-hari yang di dasarkan pada pertanyaan yang terdapat di dalam LKS. 
Pada aspek terakhir di menginferensiasi terdapat tahap menyimpulkan data hasil pengamatan. Di tahap ini siklus I, salah satu pengamat menilai bahwa siswa belum dapat melakukan penyimpulan data hasil pengamatan dengan optimal dan baik. Karena siswa belum paham cara menyimpulkannya dengan benar dan guru tidak membimbing seluruh kelompok siswa cara menyimpulkan hasil pengamatan dengan baik dan benar. Berdasarkan siklus I yang telah dilakukan refleksi maka dilakukan siklus II, di siklus II siswa sudah dapat menyimpulkan data hasil pengamatan dengan optimal dan baik, karena guru sudah mampu membimbing siswa untuk menyimpulkan data hasil pengamatan yang telah di lakukan kelompok siswa. Menurut Mahmudah, (2016) Membuat kesimpulan sementara atau inferensi sering dilakukan oleh ilmuwan dalam proses penelitiannya. Guru melatih peserta didik dalam menyusun suatu kesimpulan sementara dalam proses penelitian sederhana yang dilakukan. Sedangkan menurut Uno dalam Mahmudah, (2016) bahwa membuat kesimpulan sementara atau inferensi adalah keterampilan untuk memberikan kata sepakat yang sifatnya sementara. Kesimpulan dibuat berdasarkan informasi yang diperoleh dan berlaku sampai batas waktu tertentu.

\section{d. Mengkomunikasikan}

Pada aspek terakhir yang diamati untuk melihat keterampilan proses dasar siswa yaitu mengkomunikasikan jawaban secara lisan. Menurut Trianto (2011) pengkomunikasian adalah mengatakan apa yang anda ketahui dengan ucapan kata-kata, tulisan, gambar, demostrasi, atau grafik. Sedangkan menurut Mahmudah (2016) Keterampilan mengkomunikasikan ini diantaranya sebagai berikut: a) Mengutarakan suatu gagasan b.
Menjelaskan penggunaan data hasil penginderaan/memeriksa secara akurat suatu objek atau kejadian c. Mengubah data dalam bentuk tabel ke bentuk lainnya misalnya grafik, peta secara akurat.Di siklus I tahap mengkomunikasikan berjalan dengan baik yang dilakukan secara optimal oleh guru dan siswa. Hal ini dapat berjalan dengan baik karena guru membimbing siswa untuk mengkomunikasikan hasil pengamatannya yaitu dengan menyuruh salah satu perwakilan setiap kelompok untuk mengkomunikasikan hasil pengamatan yang telah di lakukan di depan kelas. Pada siklus II yang sudah dilakukan dengan merefleksi siklus I maka siklus II dapat berjalan dengan baik dan dilakukan secara optimal.

\section{PENUTUP}

\section{Simpulan}

Kesimpulan Penelitian Tindakan Kelas (PTK) yang telah dilakukan di Kelas $\mathrm{VII}_{2}$ SMPN 8 Kota Bengkulu yang menerapkan model discovery learning dapat disimpulkan bahwa keterampilan proses dasar IPA siswa secara keseluruhan dikategorikan baik dan meningkat dari siklus I ke siklus II.

\section{Saran}

Saran yang perlu dipertimbangkan yaitu untuk meningkatkan keterampilan proses dasar siswa perlu diterapkan Discovery learning secara berkala.

\section{DAFTAR PUSTAKA}

Arikunto, S. (2013). Dasar-Dasar Evaluasi Pendidikan. Jakarta: PT Bina Aksara.

Buana. (2017). Model Pembelajaran Discovery Learning dan Penerapannya. Diakses 12 Agustus 2018. http://repository.unpas.ac.id/30925/3 /9a\%20BAB\%20II.pdf. 
Dimyati, dkk. (2015). Belajar dan Pembelajaran. Jakarta: Rineka cipta.

Ibrohim, dkk. (2014). Pengembangan Perangkat Pembelajaran Ipa-Biologi Berbasis Discovery-Inkuiri Dengan Sumber Belajar Potensi Lingkungan Lokal Kabupaten Pasuruan. Jurnal Biologi, Sains, Lingkungan, dan Pembelajarannya. Diakses 12 Desember $2017 \quad$ di http://jurnal.fkip.uns.ac.id/index.php/ prosbio/article/view/4997/3506.

Lestari, D. (2016). Metode Discovery Learning dan Sejarah Kebudayaan Islam (SKI). Diakses 10 agustus $2018 \mathrm{di}$ http://eprints.stainkudus.ac.id/120/5/ 5.\%20BAB\%20II.\%20pdf.pdf.

Mahmudah, L. (2016). Pentingnya Pendekatan Keterampilan Proses Pada Pembelajaran Ipa Di Madrasah. Diakses $12 \quad$ Agustus 2018 dihttp://journal.stainkudus.ac.id/inde x.php/elementary/article/view/2047.
Mahmudah, US. (2016). Keterampilan Proses Sains. Diakses 12 Agustus 2018 dihttp://eprints.walisongo.ac.id/6875/ 3/BAB\%20ll.pdf.

Permendikbud Nomor 104 tahun 2014 tentang Penilaian Hasil Belajar Oleh Pendidik Pada Pendidikan Dasar Dan Pendidikan Menengah, (Salinan).

Rusman.

(2014).

Model-model Pembelajaran. Jakarta: Rajawali Pers.

Sudijono, A. (2014). Pengantar Statistik Pendidikan. Jakarta: PT Raja Grafindo.

Trianto. (2011). Model Pembelajaran Terpadu. Jakarta: PT Bumi Aksara.

Undang-Undang Republik Indonesia nomor 20 tahun 2003 tentang Sistem pendidikan Nasional, (Salinan).

Widiasworo, E. (2017). Strategi dan Metode Mengajar Siswa di Luar Kelas (Outdoor Learning) Secara Aktif, Kreatif, inspiratif, dan Komunikatif. Yogyakarta: Ar-ruzz Media. 